\title{
DETERMINATION OF PHYSICOCHEMICAL PARAMETERS AND ANTIOXIDANT PROPERTIES OF RHUS JAVANICA LINN.
}

\author{
PACHUAU LALAWMPUII*, LALDUHSANGI HAUHNAR \\ Department of Pharmacy, RIPANS, Aizawl 796017, Mizoram, India \\ *Email: maawmi40@gmail.com \\ Received: 25 Feb 2021, Revised and Accepted: 18 May 2021
}

\begin{abstract}
Objective: The present work presents determination of physicochemical parameters of the leaves and the antioxidant properties of methanolic extract of leaves, fruits and bark of Rhus javanica $\mathrm{L}$.

Methods: The leaves of Rhus javanica L. was used for the determination of physicochemical parameters using standard protocol. The leaves, fruits and bark of the plant were extracted successively with petroleum ether, chloroform and methanol. The methanolic extracts were used to determine the antioxidant properties. The radical scavenging activity was determined with different methods like DPPH, hydrogen peroxide and hydroxyl radical scavenging assay. The reducing power was determined by reduction of ferric cyanide complex ( $\mathrm{Fe}^{3+}$ to the ferrous cyanide form (Fe $\left.{ }^{2+}\right)$. Total phenols and flavonoids concentrations were analysed using Folin-Ciocalteu's and aluminium chloride methods.

Results: The moisture content, extractive value (alcohol and water), total ash, acid insoluble ash and water-soluble ash were $0.29 \%$, $24.502 \%$, $19.314 \%, 8.2 \%, 0.45 \%$ and $4.75 \%$ respectively. The fruit extract exhibits the highest scavenging activity presented as percentage inhibition, $75.00 \pm 0.89 \%(100 \mu \mathrm{g} / \mathrm{ml})$ for DPPH free radical and $74.7 \pm 0.68 \%(100 \mu \mathrm{g} / \mathrm{ml})$ for hydrogen peroxide radical. The standard BHT (100 $\mu \mathrm{g} / \mathrm{ml})$ shows $78.5 \pm 0.43 \%$ inhibition for DPPH free radical and $82.5 \pm 0.50 \%$ inhibition for hydrogen peroxide free radical. The leaves show the highest hydroxyl radical scavenging activity, $65.00 \pm 0.40 \%(100 \mu \mathrm{g} / \mathrm{ml})$ while the standard Ascorbic acid exhibit $73.81 \pm 0.61 \%(100 \mu \mathrm{g} / \mathrm{ml})$ inhibition. The highest reducing power was shown by the bark extract but lower than the standard Ascorbic acid. The bark extract shows the highest phenolic and flavonoid content $49.86 \mathrm{mg} \mathrm{GAE} / \mathrm{g}$ and $19.38 \mathrm{mg} \mathrm{QE} / \mathrm{g}$ respectively of the dry weight of the extract.
\end{abstract}

Conclusion: The results of quantitative pharmacognostic parameters in this study is expected to be useful for setting standards for correct identification of the plant. The radical scavenging properties, total phenolic and flavonoid content also suggest that the extracts provide substantial antioxidant activities.

Keywords: Antioxidants, Physicochemical parameters, Rhus Javanica L., Soxhlet

(c) 2021 The Authors. Published by Innovare Academic Sciences Pvt Ltd. This is an open access article under the CC BY license (https://creativecommons.org/licenses/by/4.0/)

DOI: https://dx.doi.org/10.22159/ijpps.2021v13i7.41228. Journal homepage: https://innovareacademics.in/journals/index.php/ijpps.

\section{INTRODUCTION}

Pharmacognostic studies ensure plant identity, lays down standardization parameters which will help and prevents adulterations. Such studies will help in authentication of the plants and ensures reproducible quality of herbal products which will lead to safety and efficacy of natural products [1]. Many degenerative diseases are related with oxidative stress. Antioxidant is known to inhibit and reduce oxidative stress. Phenolic compounds are commonly found in plants, and they have been demonstrated to have multiple biological effects, including antioxidant activity [2, 3]. It has been reported in epidemiological studies that many of antioxidant compounds possess anti-inflammatory, antiatherosclerotic, antitumor, antimutagenic, anticarcinogenic, antibacterial and antiviral activities to greater or lesser extent [4]. Therefore, the uses of antioxidants, both natural and synthetic are gaining wide importance in prevention of diseases [5]. The synthetic antioxidants when taken in vivo lead with a lot of side effects. When they are taken as a food, it lowers the risk related to stress diseases [6].

Rhus javanica L. (Anacardiaceae) is a deciduous tree (syn. $R$. chinensis Mill.; $R$. semialata Murr.) found in the outer Himalayan ranges at an altitude of 3,000-7,000 feet, the hills of Assam, Khasia, Naga, Sikkim and Mizoram in India, upper Burma, China and Japan [7]. Rhus javanica $\mathrm{L}$. is one of the traditional medicines of Mizoram. The fruit is one of the most common fruits consumed by the people of Mizoram. Among the Mizo's the fruits is recommended for colic and diarrhoea. A decoction of the leaves is used for bathing in measles and the juice of the crushed leaves is also applied on rashes and sores caused by an allergic reaction in the skin caused by latex of Drimycarpus racemosus (Roxb.) [8]. The ripen fruits of this plant have a long history of traditional medicine use among the traditional healers of Naga tribal community in Manipur, to treat dysentery and diarrhoea as well as the other gastrointestinal disorders [9]. The present study includes determination of physicochemical parameters of the leaves and antioxidant properties of was carried out on the methanolic extracts of the leaves, fruits and bark of Rhus javanica L.

\section{MATERIALS AND METHODS}

\section{Collection of plant materials}

The leaves, fruits and bark of Rhus javanica L. were collected from Khawruhlian, Mizoram, India. Herbarium sheet of the plant was prepared and authentication was done at the Botanical Survey of India, Kolkata (Specimen No: LH-01). The specimen was preserved at the Department of Pharmacy, RIPANS, Aizawl, India.

\section{Chemicals and reagents}

Ascorbic acid, Aluminum chloride, Aluminium nitrate and Quercetin were purchased from Sigma-Aldrich. Butylated hydroxyltoluene (BHT), Butylated hydroxylanisole (BHA), Methanol, Hydrogen peroxide, Folin Ciocaltue reagent, Gallic acid, Hydrochloric acid, Sodium hydroxide, Sodium nitrite, Trichloroacetic acid were purchased from Merk. 2,2-Diphenyl-1-picrylhydrazyl (DPPH) was purchased from Himedia. The other chemicals and reagents used were also of analytical grade.

\section{Preparation of extracts}

The leaves, fruits and bark of the plant were shade dried. The leaves and bark were coarsely grounded. The dried coarsely powdered material and the fruits were extracted successively with petroleum 
ether, chloroform and methanol using hot continuous percolation method (soxhlet). The methanolic extracts were concentrated and used for the determination of antioxidant property of Rhus Javanica L.

\section{Determination of physicochemical parameters}

The physicochemical parameters such as moisture content, extractive value (alcohol soluble extractive value and water soluble extractive value, total ash, acid insoluble ash and water soluble ash were determined on the air dried leaves of the plant $[10,11]$.

\section{Moisture content}

$5 \mathrm{~g}$ of the plant material was transferred to a glass weighing bottle. The bottle along with the content was accurately weighed. The bottle was placed in an oven at $105^{\circ} \mathrm{C}$ for $5 \mathrm{~h}$, cooled to room temperature in a desiccator and weighed. Drying and weighing continued at half an hour interval until a constant weight was obtained.

\section{Extractive value}

\section{Methanol soluble extractive}

$5 \mathrm{~g}$ of the plant material was macerated with $100 \mathrm{ml}$ of methanol in a closed flask for $24 \mathrm{~h}$ by shaking frequently during the first $6 \mathrm{~h}$ and was allowed to stand for $18 \mathrm{~h}$. Then, it was rapidly filtered taking precautions against loss of ethanol. $25 \mathrm{ml}$ of the filtrate was evaporated in a tarred flat bottomed shallow dish, dried at $105^{\circ} \mathrm{C}$ and weighed. The percentage of methanol soluble extractive value was calculated with reference to the air-dried plant material.

\section{Water soluble extractive}

$5 \mathrm{~g}$ of the plant material was macerated with $100 \mathrm{ml}$ of chloroform water in a closed flask for $24 \mathrm{~h}$ by shaking frequently for the first $6 \mathrm{~h}$ and was allowed to stand for $18 \mathrm{~h}$. The extract was filtered rapidly and $25 \mathrm{ml}$ of the filtrate was evaporated to dryness in a tarred flat bottomed shallow dish, it was dried at $105^{\circ} \mathrm{C}$ and was weighed. The percentage of water soluble extractive was calculated with reference to the air-dried plant material.

\section{Determination of ash value}

\section{Total ash}

$2 \mathrm{~g}$ of the air-dried plant material was weighed accurately in a silica crucible and was incinerated at a temperature not exceeding $600{ }^{\circ} \mathrm{C}$ until free from carbon, it was cooled and weighed. The percentage of ash was calculated with reference to the air-dried plant material.

\section{Acid insoluble Ash}

The ash was boiled with $25 \mathrm{ml}$ of $2 \mathrm{M}$ hydrochloric acid for $5 \mathrm{~min}$ the insoluble matter was collected in an ash less filter paper, washed with hot water. It was ignited and cooled in a desiccator and weighed. The percentage of acid-insoluble ash was calculated with reference to the air-dried plant material.

\section{Water soluble Ash}

The ash was boiled for 5 min with $25 \mathrm{ml}$ of water, the insoluble matter was collected in an ash less filter paper, washed with hot water and ignited for $15 \mathrm{~min}$ at a temperature not exceeding $450{ }^{\circ} \mathrm{C}$. The difference in the weight of the insoluble matter and the weight of ash represented the water soluble ash. The percentage of the water soluble ash was calculated with reference to the air-dried plant material.

\section{Determination of anti-oxidant activity}

The antioxidant activity of Rhus javanica L. was carried out on the methanolic extracts of the leaves, fruits and bark. Analysis was done in triplicate for the standards and for each extract.

\section{DPPH radical scavenging activity}

The scavenging activity on 2,2-diphenyl-1-picrylhydrazyl (DPPH) free radical by the methanolic extracts was estimated according to the method described by Blois (1958) with minor changes [12] Butylated hydroxytoluene (BHT) was used as reference standard. $0.5 \mathrm{ml}$ of DPPH solution in methanol $(0.1 \mathrm{mmol})$ was mixed with
$3 \mathrm{ml}$ of each extract and $3 \mathrm{ml}$ of standard prepared in various concentrations $(10,20,40,60,80,100 \mu \mathrm{g} / \mathrm{ml})$. The extracts and standard were incubated for $30 \mathrm{~min}$ at $37{ }^{\circ} \mathrm{C}$. Absorbance was measured at $517 \mathrm{~nm}$ using ultraviolet-visible spectrophotometer. The scavenging effect of DPPH free radical was calculated using the following equation:

$$
\begin{aligned}
& \text { DPPH radical scavenging (\%) } \\
& \quad=(\text { Abs cont. }- \text { Abs ext. } / \text { Abs cont. }) \times 100
\end{aligned}
$$

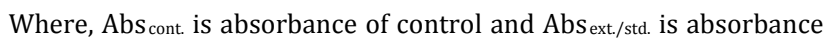
of extract/standard.

\section{Hydrogen peroxide scavenging activity}

The ability of extracts to scavenge hydrogen peroxide was determined according to the method of Ruch et al. (1989) [13]. The solution of hydrogen peroxide $(40 \mathrm{mmol})$ was prepared in phosphate buffer saline of ( $\mathrm{pH} 7.4)$, various concentrations of each extract and standard $(10,20,40,60,80$ and $100 \mu \mathrm{g} / \mathrm{ml})$ were added to hydrogen peroxide solution $(0.6 \mathrm{ml})$. Butylated hydoxytoluene (BHT) was used as a reference standard. Absorbance of hydrogen peroxide at $230 \mathrm{~nm}$ was determined after 10 min against a blank solution containing phosphate buffer without hydrogen peroxide. The percentage of hydrogen peroxide scavenging activity of both each extract and standard compound were calculated:

$$
\begin{aligned}
\mathrm{H}^{2} \mathrm{O}^{2} \text { scavenging (\%) } & \\
& =(\text { Abs cont. } \\
& \left.- \text { Abs }{ }^{\text {ext. }} / \text { Abs cont. } / \text { std. }\right) \times 100
\end{aligned}
$$

Where, $\mathrm{Abs}_{\text {cont. }}$ is absorbance of control and $\mathrm{Abs}_{\text {ext./std. is absorbance }}$ of extract/standard.

\section{Hydroxyl radical scavenging activity}

The scavenging capacity for hydroxyl radical was measured according to the modified method of Halliwell et al. (1987) [14]. Ascorbic acid was used as a standard. The assay was performed by adding $0.1 \mathrm{ml}$ of ethylenediaminetetraacetic acid (EDTA) $(1 \mathrm{mmol}), 0.01 \mathrm{ml}$ of ferric chloride $(10 \mathrm{mmol}), 0.1 \mathrm{ml}$ of hydrogen peroxide $(10 \mathrm{mmol}), 0.36 \mathrm{ml}$ of deoxyribose $(10 \mathrm{mmol}), 1 \mathrm{ml}$ of different dilutions of each extract and standard solutions $(10,20,40,60,80$, and $100 \mu \mathrm{g} / \mathrm{ml})$, dissolved in distilled water, $0.33 \mathrm{ml}$ of phosphate buffer ( $\mathrm{pH} \mathrm{7.4)}$ ), and $0.1 \mathrm{ml}$ of ascorbic acid in sequence. The mixture was then incubated at $37^{\circ} \mathrm{C}$ for $1 \mathrm{~h} .1 \mathrm{ml}$ of the incubated reaction mixture was mixed with $1 \mathrm{ml}$ of $10 \%$ trichloro acetic acid and $1 \mathrm{ml}$ of $0.5 \%$ thiobarbituric acid (in $0.025 \mathrm{M}, \mathrm{NaOH}$ and $\mathrm{BHA}$ ) to develop the pink chromagen. Absorbance was measured at $532 \mathrm{~nm}$ using UV-Vis spectrophotometer. The hydroxyl radical scavenging activity of the extract is reported as \% inhibition of deoxyribose degradation and is calculated as,

$$
\begin{aligned}
\mathrm{OH}-\text { radical scavenging }(\%) & \\
& =\left(\mathrm{Abs}{ }^{\text {cont. }}\right. \\
& \left.-\mathrm{Abs} \text { ext. }^{\mathrm{A} \text { Abs }}{ }^{\text {cont. }} /{ }^{\text {std. }}\right) \times 100
\end{aligned}
$$

Where, Abs cont. is absorbance of control and Abs ext./std is absorbance of extract/standard.

\section{Determination of reducing power}

The reducing power was determined by the method of Oyaizu (1986) using Ascorbic acid as standard [15]. $1 \mathrm{ml}$ of each extract and $1 \mathrm{ml}$ of the standard with various concentrations $(10,20,40,60,80$, and $100 \mu \mathrm{g} / \mathrm{ml}$ ) were mixed with $2.5 \mathrm{ml}$ of phosphate buffer $(6.6 \mathrm{pH})$ and $2.5 \mathrm{ml}$ of $1 \%$ potassium ferricyanide. The mixture was then incubated at $50{ }^{\circ} \mathrm{C}$ for $30 \mathrm{~min}$. The reaction was stopped by adding $2.5 \mathrm{ml}$ of $10 \%$ trichloroacetic acid and the mixture was centrifuged at $3000 \mathrm{rpm}$ for $10 \mathrm{~min} .2 .5 \mathrm{ml}$ of the supernatant was mixed with $2.5 \mathrm{ml}$ of distilled water, and $0.5 \mathrm{ml}$ of $0.1 \%$ ferric chloride solution and the absorbance was taken at $700 \mathrm{~nm}$. The reducing power of the sample is determined by increase absorbance of the standard and the sample.

\section{Determination of total phenolic content}

Total phenolic was determined using the method of Mc Donald et al. with modifications [16]. A calibration curve was prepared by mixing 
$1 \mathrm{ml}$ of methanolic solution of Gallic acid $(10,20,40,60,80$, and 100 $\mu \mathrm{g} / \mathrm{ml}$ ) with $5 \mathrm{ml}$ Folin-Ciocalteu reagent (diluted tenfold). After $3 \mathrm{~min}, 4 \mathrm{ml}$ of sodium carbonate solution $(0.7 \mathrm{M})$ was added, and the mixture was allowed to stand for $1 \mathrm{~h}$ at room temperature. Absorbance was measured at $765 \mathrm{~nm}$ using UV-Vis spectrophotometer. $1 \mathrm{ml}$ extract $(50 \mu \mathrm{g} / \mathrm{ml})$ was also mixed with the reagents above and after $1 \mathrm{~h}$ the absorbance was measured to determine total plant phenolic content. From the calibration curve, the amount of phenolic compounds was determined and expressed as milligrams of Gallic acid equivalent (GAE)/g of the dried extract.

\section{Determination of total flavonoids content}

The total flavonoid content was determined by the aluminium chloride method [17]. $1 \mathrm{ml}$ of each extract $(50 \mu \mathrm{g} / \mathrm{ml})$ was mixed with $2 \mathrm{ml}$ of distilled water. After $5 \mathrm{~min}, 3 \mathrm{ml}$ of $5 \%$ sodium nitrite $\left(\mathrm{NaNO}_{2}\right)$ and $0.3 \mathrm{ml}$ of $10 \%$ aluminium chloride $\left(\mathrm{AlCl}_{3}\right)$ were added. After $6 \mathrm{~min}, 2 \mathrm{ml}$ of $\mathrm{NaOH}(1 \mathrm{M})$ was added, and the volume was made up to $10 \mathrm{ml}$ with distilled water. After $1 \mathrm{~h}$, absorbance reading was taken at $510 \mathrm{~nm}$. A standard curve was prepared with Quercetin at different concentrations $(10,20,40,60,80$ and $100 \mu \mathrm{g} / \mathrm{ml})$. From the calibration curve of the reference standard, the total flavonoid content was determined and expressed as milligrams of Quercetin equivalent $(\mathrm{QE} / \mathrm{g})$ of the dried extract.

\section{RESULTS AND DISCUSSION}

\section{Physicochemical parameters}

The physicochemical analysis of the air dried powdered leaves was performed. The moisture content, extractive value (methanol and water), total ash, acid insoluble ash and water soluble ash are given in table 1 . The moisture content, extractive value (alcohol and water), total ash, acid insoluble ash and water soluble ash were $0.29 \%, 24.502 \%, 19.314 \%, 8.2 \%, 0.45 \%$ and $4.75 \%$ respectively. Adulteration and misidentification of crude drugs can cause serious health problems to consumers and legal problems for the pharmaceutical industries. It can be conducted via a variety of techniques, namely macro and microscopic identification and chemical analysis especially description of microscopic botanical aspects to determine definitively the proper species of plant material while it is still in its non-extracted from [18]. The ash values are particularly important to find out the presence or absence of foreign inorganic matter such as metallic salts and or silica (earthy matter) [19]. The water-soluble ash is used to estimate the amount of inorganic compound [20]. Acid insoluble ash provides information about non-physiological ash produced due to adherence of inorganic dirt, dust to the crude drug. Increased acid insoluble ash indicates adulteration due to dirt, sand (or) soil. The extractive values are primarily useful for the determination of exhausted or adulterated drug and helpful in the detection of adulteration [21].

Table 1: Physicochemical parameters of the leaves of Rhus javanica $\mathrm{L}$.

\begin{tabular}{ll}
\hline Parameters & Rhus javanica $\mathbf{L}$. \\
\hline Moisture content & $0.29 \%$ \\
Water soluble extractive & $24.502 \%$ \\
Methanol soluble extractive & $19.314 \%$ \\
Total ash value & $8.2 \%$ \\
Acid insoluble ash & $0.45 \%$ \\
Water soluble ash & $4.75 \%$ \\
\hline
\end{tabular}

\section{In vitro antioxidant activity}

\section{DPPH radical scavenging activity}

The antioxidant activity of the extracts and the standard antioxidant BHT, expressed as the percentage scavenging activity of the DPPH free radicals is given in fig. 1 . The extracts show inhibition ranging from $34.56 \pm 0.69$ to $75.00 \pm 0.89 \%$. Among the extracts the highest scavenging activity $75.00 \pm 0.89 \%$ is shown by the fruit extract at 100 $\mu \mathrm{g} / \mathrm{ml}$, followed by $68.41 \pm 0.59 \%$ exhibited by $80 \mu \mathrm{g} / \mathrm{ml}$ of the fruit extract and $67.33 \pm 0.24 \%$ exhibited by $100 \mu \mathrm{g} / \mathrm{ml}$ of the bark extract. The standard antioxidant BHT exhibit $78.50 \pm 0.43 \%$ inhibition at $100 \mu \mathrm{g} / \mathrm{ml}$. DPPH is a free radical which is stable at room temperature, and this method is often employed to determine the antioxidant activity of many plant extracts. DPPH is a stable nitrogen-centered free radical, the color of which changes from violet to yellow upon reduction by either the process of hydrogen-or electron-donation. Substances which are able to perform this reaction can be considered antioxidants and, therefore, radical scavengers [22].

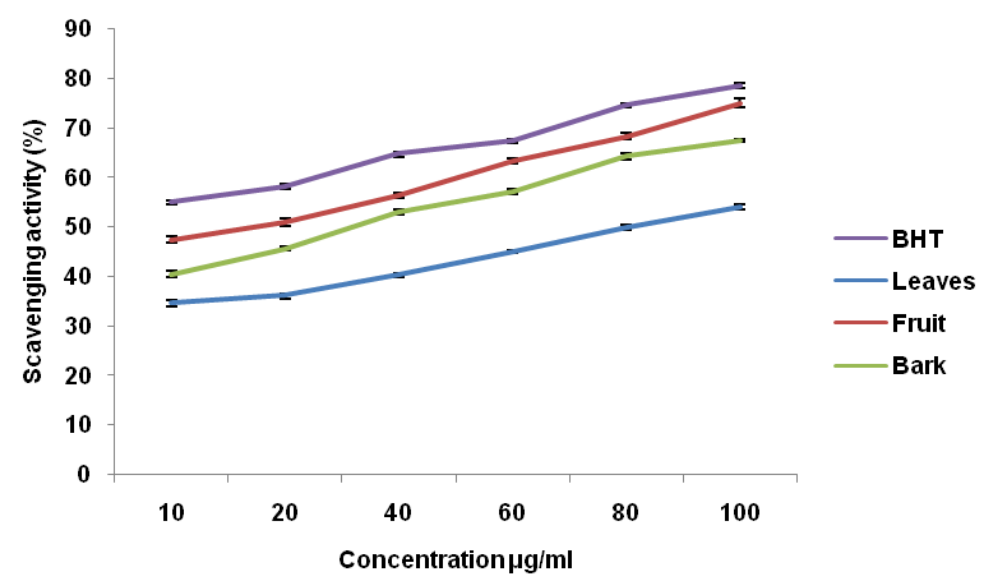

Fig. 1: DPPH radical scavenging activity of extracts of Rhus javanica L. Values are expressed as mean \pm SEM. Each value is the mean of three (03) essays $(n=3)$

\section{Hydrogen peroxide scavenging activity}

The antioxidant activity of the extracts and the standard antioxidant BHT, expressed as the percentage scavenging activity of hydrogen peroxide is given in fig. 2 . The extracts show inhibition ranging from $27.65 \pm 0.70 \%$ to $74.70 \pm 0.69 \%$. Among the extracts the highest scavenging activity $74.70 \pm 0.68 \%$ is shown by the fruit extract at 100 $\mu \mathrm{g} / \mathrm{ml}$, followed by $66.62 \pm 0.40$ exhibited by $80 \mu \mathrm{g} / \mathrm{ml}$ of the fruit extract and $66.48 \pm 0.48 \%$ exhibited by $80 \mu \mathrm{g} / \mathrm{ml}$ of the leaves extract. The standard antioxidant, BHT exhibit $82.50 \pm 0.50 \%$ inhibition at $100 \mu \mathrm{g} / \mathrm{ml} . \mathrm{H}_{2} \mathrm{O}_{2}$ is highly important because of its ability to penetrate into biological membranes. $\mathrm{H}_{2} \mathrm{O}_{2}$ itself is not very reactive, but it can sometimes be toxic to cell because it may give rise to hydroxyl radicals in the cells [23] $\mathrm{H}_{2} \mathrm{O}_{2}$ has no direct effect on DNA but can damage DNA by producing hydroxyl radical $\left(\mathrm{OH}^{-}\right)$in the presence of transition metal ions [24]. Scavenging of $\mathrm{H}_{2} \mathrm{O}_{2}$ by extracts may be attributed to their phenolics, which can donate electrons to $\mathrm{H}_{2} \mathrm{O}_{2}$, thus neutralizing it to water [25]. The results show the all the extracts had $\mathrm{H}_{2} \mathrm{O}_{2}$ scavenging activity which may be due to the antioxidant compounds. 


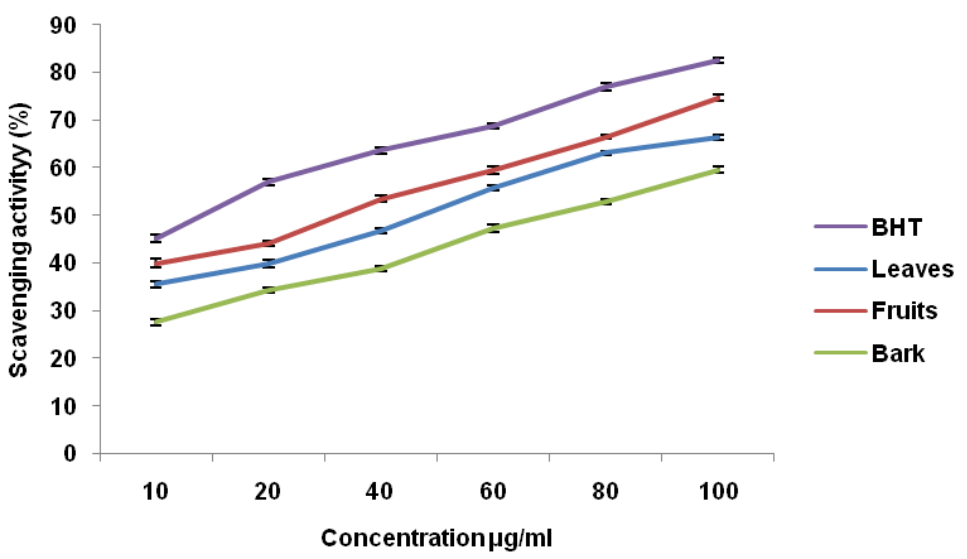

Fig. 2: Hydrogen peroxide scavenging activity of extracts of Rhus javanica L. Values are expressed as mean \pm SEM. Each value is the mean of three (03) essays $(n=3)$

\section{Hydroxyl radical scavenging activity}

The antioxidant activity of the extracts and the standard antioxidant ascorbic acid, expressed as the percentage scavenging activity of hydrogen peroxide is given in fig. 3. The extracts show inhibition ranging from $21.00 \pm 0.58$ to $65.00 \pm 0.40 \%$. Among the extracts the highest scavenging activity $65.00 \pm 0.40 \%$ was shown by the leaves extract at 100 $\mu \mathrm{g} / \mathrm{ml}$, followed by $56.63 \pm 0.51 \%$ exhibited by $80 \mu \mathrm{g} / \mathrm{ml}$ of the leaves extract and $51.20 \pm 0.49 \%$ exhibited by $60 \mu \mathrm{g} / \mathrm{ml}$ of the leaves extract.
The standard antioxidant, ascorbic acid exhibit $73.81 \pm 0.61 \%$ inhibition at $100 \mu \mathrm{g} / \mathrm{ml}$. The hydroxyl radicals are highly active of the reactive oxygen species, which cause severe injury in adjacent biomolecules or they cause oxidative stress to nucleic acids, proteins and lipids [26] Hydroxyl radicals are formed by incubating $\mathrm{Fe}^{+3}$-EDTA premixture with ascorbic acid and $\mathrm{H}_{2} \mathrm{O}_{2}$ at pH 7.4, causing 2-deoxy-D-ribose degradation and generating a malondialdehyde (MDA)-like product [27]. The addition methanolic extracts of Rhus javanica L. to the reaction mixture removes hydroxyl radicals and prevents further damage.

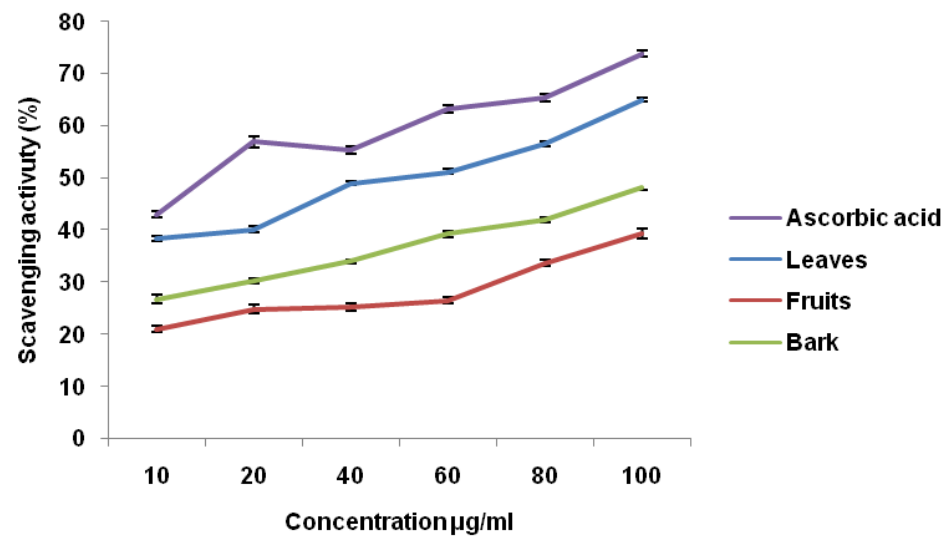

Fig. 3: Hydroxyl radical scavenging activity of extracts of Rhus javanica $L$. Values are expressed as mean \pm SEM. Each value is the mean of three (03) essays $(n=3)$

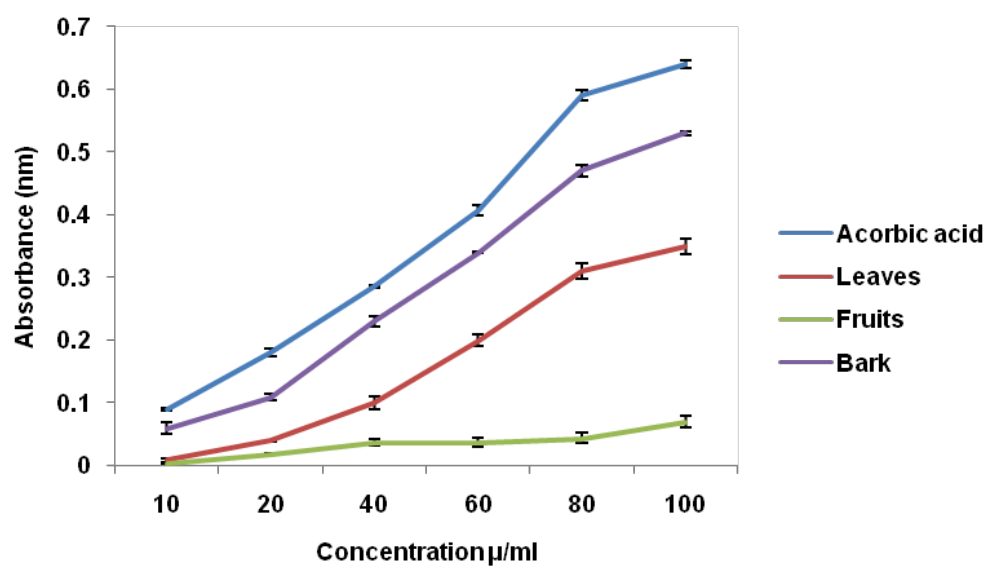

Fig. 4: Reducing power activity of extracts of Rhus javanica L. Values are expressed as mean \pm SEM. Each value is the mean of three (03) essays ( $n=3)$ 


\section{Reducing power}

The reducing power assay is often used to evaluate the ability of an antioxidant to donate an electron. The concentration of ferrous ions can be determined by absorbance measurement at $700 \mathrm{~nm}$. Increased absorbance of the reaction mixture indicated increased reducing power of the extracts as shown in fig. 4 . In this assay, the reducing power of the extract increased with the increase in their concentration suggesting that some compounds in the extract may be able to donate hydrogen atom to break the free radical chain reaction. The presence of an antioxidant in the extract resulted in reduction of the ferric cyanide complex $\left(\mathrm{Fe}^{3+}\right)$ to the ferrous cyanide form $\left(\mathrm{Fe}^{2+}\right)$. Since the absorbance of the reaction mixture increases it indicated increased reducing power of the extracts and thus proved that the extracts possess reducing power even though the reducing power of the extracts were lower than the standard ascorbic acid
The bark extract at $100 \mu \mathrm{g} / \mathrm{ml}(0.5 \mathrm{~nm})$ shows the highest reducing power among the three extracts.

\section{Total phenolic content}

Total phenols are reported as Gallic acid equivalents (GAE) by reference to a standard curve shown in fig. 5. Phenolics or polyphenols are plant secondary metabolites and are very important by virtue of their antioxidant activity by chelating redox active metal ions, inactivating lipid free radical chains and preventing hydroperoxide conversation into reactive oxyradicals [28]. Gallic acid being the most important polyphenol in natural products was used to determine phenolics of tested plant methanolic extracts. The total phenolic content of the leaves, fruits and bark of Rhus javanica L. were found to be $36.16,47.00$ and $49.86 \mathrm{mg} \mathrm{GAE} / \mathrm{g}$ dry weight of the methanolic extracts respectively.

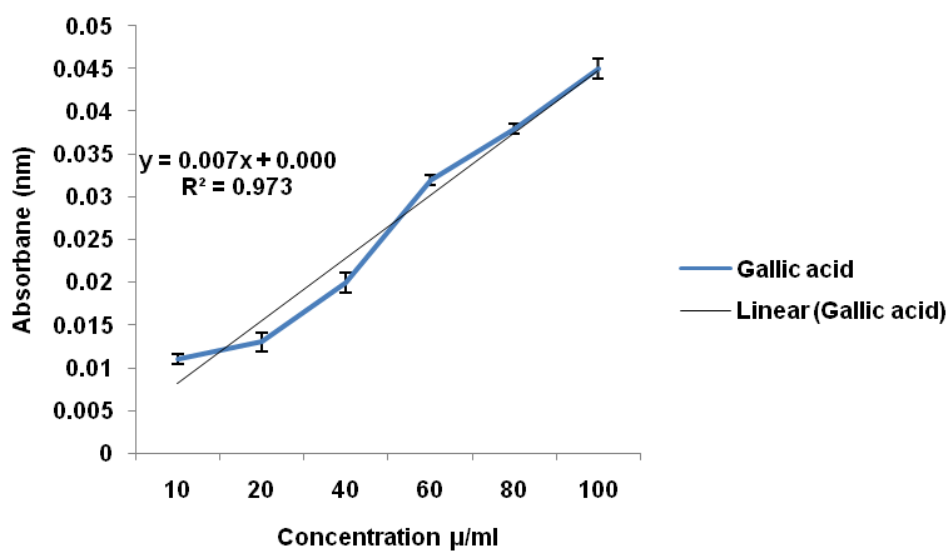

Fig. 5: Standard calibration curve for quantification of phenolic content. Values are expressed as mean \pm SEM. Each value is the mean of three (03) essays $(n=3)$

\section{Total flavonoid content}

Total flavonoid content is expressed as mg of Quercetin Equivalents (QE) by reference to quercetin standard curve in fig. 6. The total flavonoid content of the leaves, fruits and bark of Rhus javanica L. were found to be $11.86,10.1$ and $19.38 \mathrm{mg}$ QE/g dry weight of the methanolic extracts respectively. Flavonoids possess many biochemical properties, but the best described property of almost every group of flavonoids is their capacity to act as antioxidants. The antioxidant activity of flavonoids depends upon the arrangement of functional groups about the nuclear structure. The configuration, substitution, and total number of hydroxyl groups substantially influence several mechanisms of antioxidant activity such as radical scavenging and metal ion chelating ability $[29,30]$.

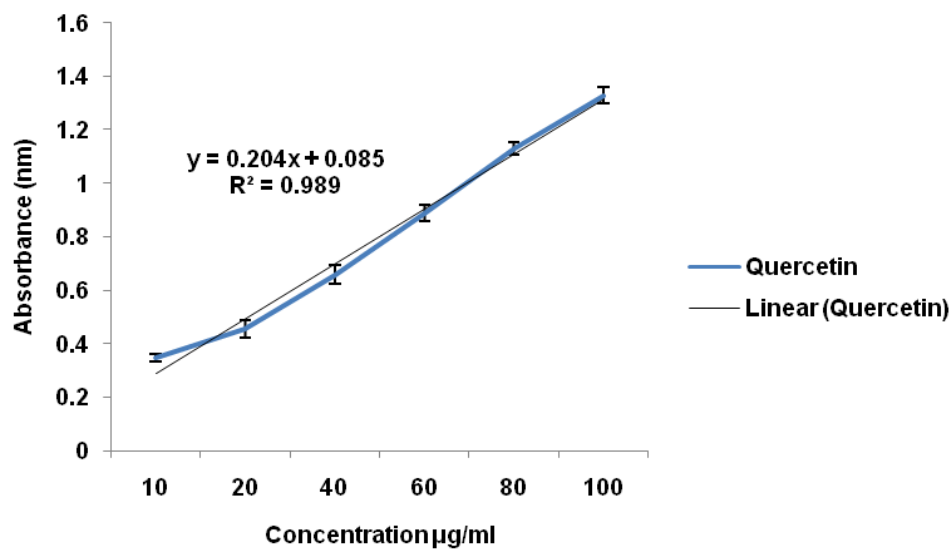

Fig. 6: Standard calibration curve for quantification of flavonoid content. Values are expressed as mean \pm SEM. Each value is the mean of three (03) essays $(n=3)$

\section{CONCLUSION}

The physicochemical parameters present in this work may contribute in the authentication and identification of Rhus javanica Linn. The result of the present study showed that all the plant extracts have potent antioxidant property, which proves its benefit as an antioxidant source. Since the fruit is already consumed as it is, it has a good potential to be developed into a nutraceutical, both as the main ingredient or in combination with other herbal drugs. The plant may be studied for its various potential health benefit and 
further isolation and identification of unknown bioactive compounds are required to study their pharmacological activities.

\section{FUNDING}

Nil

\section{AUTHORS CONTRIBUTIONS}

1. Pachuau Lalawmpui: Select the experiment protocol, carrying out the experiment and writing the manuscript.

2. Lalduhsangi Hauhnar: Collect the plant material, send for authentication, carrying out the experiment and contribute in writing the manuscript.

\section{CONFLICT OF INTERESTS}

\section{Declared none}

\section{REFERENCES}

1. Chanda S. Importance of pharmacognostic study of medicinal plants: an overview. J Pharmacogn Phytochem 2014;2:69-73.

2. Xia DZ, Yu XF, Zhu ZY, Zou ZD. Antioxidant and antibacterial activity of six edible wild plants (Sonchus spp.) in China. Nat Prod Res 2011;25:1893-901.

3. Thaipong K, Boonprakob U, Crosby K, Zevallos LC, Byrne DH. Comparison of ABTS, DPPH, FRAP and ORAC assays for estimating antioxidant activity from guava fruit extracts. J Food Compos Anal 2006;19:669-75.

4. Uttara B, Singh AV, Zamboni P, Mahajan RT, Sing AV, Zamboni BUP, et al. Oxidative stress and neurodegenerative diseases: a review of upstream and downstream antioxidant therapeutic options. Curr Neuropharmacol 2009;7:65-74.

5. Saumya SM, Mahaboob BP. In vitro evaluation of free radical scavenging activities of Panax ginseng and Lagerstroemia speciosa: a comparative analysis. Int J Pharm Pharm Sci 2011;3:165-9.

6. Ida Christi VE, Uma Poorani T, Nagarajaperumal G, Mohan S. Phytochemicals detection, antioxidant and antimicrobial activity study on berries of Solanum torvum. Asian J Pharm Clin Res 2018;11:418-23.

7. Bose SK, Dewanjee S, Gupta AS, Kartick C, Samanta KC, Kundu $\mathrm{M}$, et al. In vivo evaluation of antidiarrhoeal activity of Rhus semialata fruit extract in rats. Afr J Tradit Complement Altern Med 2008;5:97-102.

8. Sawmliana M. The Book of mizoram plants. $1^{\text {st }}$ ed. Aizawl: Loisbet Offset; 2003.

9. Tangpu V, Yadav A. Antidiarrhoeal activity of Rhus javanica ripen fruit extract in albino mice. Fitoterapia 2004;75:39-44.

10. World Health Organization (WHO). Quality control methods for medicinal plant materials. WHO/PHARM/92.559. Geneva: World Health Organization (WHO); 1998.

11. Anonymous. Ayurvedic pharmacopoeia of India part-I Vol. IX. Ghaziabad (U. P.): Pharmacopoeia commission for Indian medicine and homoeopathy; 2016.

12. Blois MS. Antioxidant determinations by the use of a stable free radical. Nature 1958;181:1199-200.
13. Ruch RJ, Cheng SJ, Klaunig JE. Prevention of cytotoxicity and inhibition of intracellular communication by antioxidant catechins isolated from Chinese green tea. Carcinogenesis 1989;10:1003-8.

14. Halliwell B, Gutteridge JM, Aruoma OI. The deoxyribose method: a simple "test-tube" assay for determination of rate constants for reactions of hydroxyl radicals. Anal Biochem 1987;165:215-9.

15. Oyaizu M. Studies on products of browning reactionantioxidative activities of products of browning reaction prepared from glucosamine. Japan J Nutr Diet 1986;44:307-15.

16. McDonald S, Prenzler PD, Antolovich M, Robards K. Phenolic content and antioxidant activity of olive extracts. Food Chem 2001;73:73-84

17. Chang CC, Yang MH, Wen HM, Chern JC. Estimation of total flavonoid content in propolis by two complementary colorimetric methods. J Food Drug Anal 2002;10:178-82.

18. Periyanayagam K, Kasirajan B, Karthikeyan V, Jancy Gracelet R, Kumuda T. Quality assessment profile of the leaves of Vitis vinifera L. (Vitaceae)-An important phytotherapy component of tropical diseases control. Innovare J Health Sci 2013;1:26-31.

19. Agrawal SK, Karthikeyan V, Parthiban P. Pharmacognostic and physiochemical standardization of the leaves of Scoparia dulcis L. Int J Univers Pharm Bio Sci 2014;3:131-44.

20. Jothi G, Keerthana K, Sridharan G. Pharmacognostic physicochemical, and phytochemical studies on stem bark of Zanthoxylum armatum DC. Asian J Pharm Clin Res 2019;12:1-5.

21. Thomas S, Patil DA, Patil AG, Chandra N. Pharmacognostic evaluation and physicochemical analysis of Averrhoa carambola L. fruit. J Herb Toxicol 2008;2:51-4.

22. Dehpour AA, Ebrahimzadeh MA, Nabavi SF, Nabavi SM. Antioxidant activity of methanol extract of Ferula asafoetida and its essential oil composition. Grasas Aceites 2009;60:405-12.

23. Gulcin I, Huyut Z, Elmastas M, Aboul Enein HY. Radical scavenging and antioxidant activity of tannic acid. Arab J Chem 2010;3:43-53.

24. Halliwell B, Clement MV, Long LH. Hydrogen peroxide in the human body. FEBS Lett 2000;486:10-3.

25. Ebrahimzadeh MA, Nabavi SF, Nabavi SM. Antioxidant activities of methanol extract of Sambucus ebulus L. flower. Pak J Biol Sci 2009; $12: 447-50$.

26. Jacob J, John M. Phytochemical screening and evaluation of leaf parts of hypoestes phyllostachya rosea for in vitro antioxidant activities. Int J Curr Pharm Res 2020;12:54-8.

27. Rahman MM, Islam MB, Biswas M, Khurshid Alam AHM. In in vitro antioxidant and free radical scavenging activity of different parts of Tabebuia pallida growing in Bangladesh. BCM Res Notes 2015;8:261-9.

28. Rice Evans CA, Miller NJ, Paganga G. Structure-antioxidant activity relationships of flavonoids and phenolic acids. Free Radical Biol Med 1996;20:933-56.

29. Heim KE, Tagliaferro AR, Bobilya DJ. Flavonoid antioxidants: chemistry, metabolism and structure-activity relationships. J Nutr Biochem 2002;13:572-84.

30. Pandey AK, Mishra AK, Mishra A. Antifungal and antioxidative potential of oil and extracts derived from leaves of Indian spice plant Cinnamomum tamala. Cell Mol Biol 2012;58:142-7. 